\title{
Industrial Unionism and Its Bargaining Correlates in Nigeria Industrial Relations System
}

\author{
Francis C. Anyim ${ }^{1}$, Joy Onyinyechi Ekwoaba ${ }^{1} \&$ Adedoyinsola Olajumoke Shonuga ${ }^{1}$ \\ ${ }^{1}$ Department of Industrial Relation \& Personnel Management, Faculty of Business Administration, University of \\ Lagos, Akoka Yaba, Nigeria \\ Correspondence: Francis C. Anyim Ph.D, FCIPM, FNIM, FCAI, FABS, Department of Industrial Relation \& \\ Personnel Management, Faculty of Business Administration, University of Lagos, Akoka Yaba, Nigeria. Tel: \\ 234-803-346-8317. E-mail: chucksanyim2004@yahoo.com
}

Received: December 14, 2012

Accepted: May 16, 2013

Online Published: August 1, 2013

doi:10.5430/jms.v4n3p56

URL: http://dx.doi.org/10.5430/jms.v4n3p56

\begin{abstract}
Between 1960-1966, industrial relations system in Nigeria was based on Laissez-faire doctrine or voluntary ethic. The colonial trade union ordinance of 1938 allowed any five or more persons to form trade unions. The trend led to the proliferation of over 1000 mushroom unions which were not well organized and badly managed. Besides, all was not well with the organization, administration, finance, leadership and foreign relations of the unions. It was against this backdrop that government initiated a move to restructure the trade unions along industrial lines.

The objective of this paper is to highlight the impact of industrial unionism on industrial relations system in Nigeria and also to examine the implications and changes it has created in the pattern of collective bargaining especially the multi-employer bargaining. The paper in its methodology adopted a theoretical approach which was blended with the authors' versed and practical knowledge of the subject and trend of events. The paper concludes with recommendations on ways to make the multi-employer bargaining more effective or result-oriented.
\end{abstract}

Keywords: commission, industrial unionism, joint industrial council, laissez-faire, multi-employer bargaining, national policy on labour, restructuring

\section{Introduction}

Prior to the restructuring of the trade unions in Nigeria along industrial line in mid '70, the structure of Nigeria trade unions was diverse, be - wildering and disorderly. This was due partly to the fact that no deliberate attempt were made to regulate their structure by legislation and partly due to the fact that they grew in fulfillment of pressing needs that allowed little time for serious planning. Amongst other factors that exacerbated the problem are: the organization of industry and their geographical distribution; the attitude of employers and trade union leaders; and the permissive and porous nature of the then Trade Unions Act. The structure appeared to be damaging to the national economy and also a hindrance to efficient running of industry and commerce.

There have been instances where strikes have caused jurisdictional disputes in which two competing unions differ as to which of them should organize a given group of workers. With respect to disputes over wages, some unions try to score off others in competitive terms whereas if only one union was involved in each industry, the chances of jealousy arising from multiple negotiations would be very remote. The structure under discourse created complicated problem for establishments as several unions organized workers in a single establishment. Furthermore, efficient operation of industry was impeded because decisions have to be taken in a such a way to accommodate the different pressures and demands from competing unions which were not in line with the needs of the enterprise.

Turning to the institution of collective bargaining, the trend prevented the development of industrial-wide bargaining with the benefits attached to it. The ineffective structure was a stumbling block towards the stimulation of the development of employers organizations. More worrisome was the multiplication of trade disputes over the right of union or interest representation.

It was against this background and the expressed desire for a well organized trade union structure and responsible unionism that the government restructured the trade unions along industrial lines. Industrial unionism involves the organization of workers in a given industry or group of related industries regardless of occupation. The emergence of 
industrial unionism led to significant changes in other spheres of industrial relations practice in Nigeria which stands as the focus of this presentation.

\section{Literature Review}

\subsection{The Origin Trade Unions in Nigeria}

The rise of trade unionism in Nigeria cannot be dissociated from the $17^{\text {th }}$ century Euro-African trade. This trade introduced the money economy which gradually replaced the system of barter and almost simultaneously marked the beginning of paid labour (Adewumi, 2004). Apart from increased demand for employable labour which the trade generated, the gradual presence of the colonial administration and the emergence of other commercial concerns dictated the need for more infrastructures, hence the construction of more roads, bridges, rail lines, ports and military bases. All these increased the pool of employed labour as well as took their tool on Nigerian workers (Ananaba, 1969).

According to Fashoyin (1980) one of the first major attempts made by Nigerian Workers to assert their rights was by artisans workmen in the Public Works Department (P.W.D) in 1897 who went on a three day strike to protest the arbitrary change in their hours of work. The action was strongly countered by the then colonial governor who threatened to deal with the striking workers if they continued with their action. The workers were undaunted and the governor agreed to negotiate.

The history of the trade union movement in Nigeria has been well documented. Its travails and triumphs as well as the potentials and shortcomings have been highlighted by such writers as, Offiong (1987), Otobo (1986) and Aborishade (1992) among others. Available records indicate that the first trade union to emerge was Southern Nigerian Civil Service Union inaugurated on the $19^{\text {th }}$ August, 1912, and subsequently changed to the Nigerian Civil Service Union (N.C.S.U) in 1914 after the amalgamation of the Northern and Southern Protectorates. One major issue addressed by the union was the discrimination between African and European civil servants.

Active trade unionism in Nigeria can be said to begin in the early 1930s, a period which witnessed persistent workers agitation and restiveness spear-headed by the more radical railway workers who severed their membership of NCSU and formed the Railway Workers Union (R.W.U) in 1931, the major arguments against the NCSU were that it was too soft-spoken and unresponsive to the economic hardship.

In 1938, Trade Union Ordinance, which formally legalized trade unionism and made for compulsory registration of unions in Nigeria was enacted. The law made it unlawful for any union to engage in collective bargaining or embark on industrial action without registration under its provisions. Reasons for the enactment of this law cannot be unconnected with the series of riots, strikes and rebellions that plagued the British Colonies in West Indies and Northern Rhodesia first in 1933 and again in 1937, coupled with the general restiveness of workers occasioned by the hardships they had to contend with (Adewumi, 2004).

\subsection{Restructuring of Trade Unions in Nigeria}

Aside from the Trade Union Ordinance which gave legal backing to trade unionism in Nigeria, the example of the Railway workers' union was one of the factors responsible for the upsurge in the number of unions. The concessions gained by the railway workers were pointers to other workers that similar possibilities could come to them. Added to the fact that any five workers could combine to form a trade union, many unions emerged leading to what has been described as the proliferation of unions with many of them having less than 250 members (Fashoyin, 1992).

The situation seriously militated against the healthy advancement of the interests of the working masses and this was by no means helped by the divisive strategies and acrimonious rivalry among the existing central labour organizations. It was within this setting that the Nigerian state got an excuse to promulgate the Trade Union (Central Labour Organizations) Decree No.44 of 1976. Among other things, it cancelled the registration of the existing central labour organizations, and placed an embargo on the registration of new trade unions. More importantly, an Administrator of Trade Unions was appointed and mandated among other things to take all necessary steps to effect the formation of a single central labour organization to which all trade unions in Nigeria must be affiliated, and to restructure the existing numerous house unions into fewer, stronger and more effective industrial unions.

The exercise culminated in the promulgation of the Trade Unions (Amendment) Decree No.22 of 1978, which provided statutory recognition for 70 unions including 42 industrial unions, which emerged out of the restructuring exercise. The restructuring exercise also led to the emergence of the Nigeria Labour Congress (NLC) as the only central trade union body in Nigeria to which all the industrial unions (as defined by the enabling law) are affiliated. Further restructuring led to emergence of the present 29 industrial unions in 1999 (Anyim, 2009). 


\subsection{Trade Unions and Organizational Process}

Despite sustained hostility from some employers and occasional state repression coupled with membership passiveness and indifference of the public, trade unions remain an enduring institution in the employment relations. This much is admitted by Mulvey (1978) as he acknowledges that in most of the industrial countries the most pervasive institution is the trade union movement. Trade unions developed in response to challenges thrown up by the new organization of work and production built around the factory system that emerged as the new centre of economic activities after the industrial revolution in the 17th and early 18th centuries. They emerged without the prompting of governments and employers and also as independent organizations of workers without any legal backing. They first emerged in England and it was not until 1824 that the legal encumbrance was removed.

According to Otobo (1996), unions carry on many different activities. Most visible to the average member are those which produce direct benefit-negotiations, grievance handling, community service, and uncertain trades, job search or referral. Another type of activity arises from the internal politics of the union. It consists of elections, meetings, conventions and similar forums in which members participate in governing the union. But to be effective a union must build and maintain itself as on organization. This entails bringing in members through organizing and keeping the union running smoothly through union administration and effective internal communications. Otobo (1996) further states that trade unions occupy a special position because they are organizations of wage earners, workers, and quite often they are about the only other group in society that has as its main duty or responsibility to react to the industrial and socio-economic policies of government and of private employers and try to protect the interest of members within individual enterprises. The industrial trade unions are by their nature and structure basically democratic institutions whatever, their other failures. And within and outside of their executives and central working committees, state or zonal branches, members can always propose and oppose any line of action. From the foregoing, union leaders cannot be seen or taken as dictators that can impose an unpopular position or stance on members. Members would either throw them out, or when not possible because of union constitutional provisions can bypass such leaders. Okogwu (1996) also agrees with Otobo when he asserts that in addition to increasing wages and improving conditions of employment, trade unions provide workers both with protection against arbitrary management decisions and with a voice at the place of work and in the political arena.

Like its counterparts in different parts of the world, the Nigerian trade union movement has a glorious past, a past characterized by robust struggles and principled opposition to state policies that are inimical to the interests of the working people. It is also a past that was characterized by conscious efforts at mobilizing the rank-and-file members as a bulwark against state repression. The past equally witnessed the building of alliances between the trade union movement and various elements and organizations within the larger labour movement. All these constituted the pillars of strength of the trade union movement (Adewumi, 1997).

Nigerian Trade Union movement comprises a variety of unions that represent the specific interest of workers. They engage in struggling for the rights and welfare of workers, specifically, for decent wages and improved conditions of service, where negotiations fail to achieve the desired result, trade unions are noted for resorting to radical action such as stay at homes, work to rule, demonstrations and street protests - which are capable of not only grounding the particular production process but, sometimes and more crucially, the economy (Tai, 2009). They have become the voice of the voiceless, platform for the unheard and downtrodden, and the hope of the masses (Imhonopi and Urim, 2011). Thus, there is no doubt that trade unions in Nigeria have come a long way in enhancing the economic well-being of its members. It has even passed through the burning and fiery flame doing so (Ademiluyi and Imhonopi, 2010).

\section{The Concept of Industrial Unionism in Nigeria}

\subsection{Histroical Development of Industrial Unionism in Nigeria}

One of the characteristics of industrial relations in Nigeria from the early 40s has been the use by Government of Commissions as a vehicle for all major wages and salaries reviews. Examples are:
(i) Tudor Davis Commission
(ii) Harragin Commission
(iii) Miller Commission
(iv) Gorsuch Commission
(v) Mbanefo Commission
(vi) Morgan Commission 
(vii) Adebo Commission

1970

(viii) Udoji Commission

From records, it was Morgan Commission that first muted and conceived the idea on the necessity for the establishment of Joint Industrial Councils (JIC) which came as the fore-runner of the present day industrial unionism in Nigeria.

The Morgan Commission after taking evidence extensively from employers, trade unions and members of the public felt that the problems arising out of levels of wages and salaries in the main and other conditions of service to a less extent seem to determine the kind of industrial relations atmosphere that existed. It identified three basic methods by which wages, salaries and conditions of service to a less extent seem to determine the kind of industrial relations atmosphere that existed. The first the Commission regarded as no system at all left wages to be determined directly by individual worker and his/her employer; the second method is by the state, and the third by the process of voluntary collective bargaining by groups of workers and employers. The Commission went on to prove that it was nonetheless the state policy in Nigeria that salaries and wages indeed the whole fabric of industrial relations should be fashioned, altered and sustained by means of free collective bargaining (Omolayole, 1977). Consequently, to make for an effective collective bargaining in all sectors of the Nigerian economy the Commission recommended very strongly the establishment of a Joint Industrial Council for each major industry or groups of similar industries and/or employments. The rationale for the Morgan Commission's recommendation is that wage and salary reviews deserve to be undertaken on a continuing basis through a negotiating machinery.

Due to increasing crisis and fragmentation of the trade unions in the $60 \mathrm{~s}$, recommendations were made for the creation of industrial unions. One of such recommendations came during the National Conference on industrial Relations in 1965 at the University of Ibadan. The discussion group on industrial relations commenting on the trade union structure states that "apart from the Nigerian Union of Teachers the Nigerian Union of Railwaymen and the Nigeria Civil Service Union, most of the then 600 odd registered trade unions in Nigeria were too small and weak to fulfill effectively the objects for which they were established. The Committee was of the opinion that the industrial pattern of trade union organization will best suit the conditions in Nigeria".

The foregoing line of thought was picked up by the Adebo Commission of 1970-1971. In the Commission's view, "the proliferation of trade unions in Nigeria was a crying scandal. Our labour movement consisted of some 700 unions purporting to cater for the interests of under a million wage and salary earning population. It is hardly surprising that there is a lack of personnel with suitable background and experience to give the right leadership. The first and most important element of reform is in our view the restructuring of Nigerian Labour Unions into industrial unions".

The first practical step at the creation of industrial unions and towards the modification of industrial relations system in Nigeria was taken on $4^{\text {th }}$ December, 1975. In an address to representatives of the then Central Labour Organizations and the Employers' Consultative Association (NECA) on the new National Policy on Labour at a meeting held at the Senate Chamber of the University of Ibadan, the then Federal Commissioner for Labour, late Major General Henry Adefope announced the decision of the then Federal Military Government in Nigeria to formulate a new Labour Policy whose objectives among others included the need to rationalize the structure and organization of trade unions and to ensure that they are self-sufficient financially and not to depend upon foreign sources of finance.

As a follow up of the new National Labour Policy, the Trade Unions (Central Labour Organization) (Special Provisions) Decree NO.23 of 1976 was promulgated. By the Decree, an Administrator of Trade Union Affairs was appointed and charged with the responsibility of restructuring the trade unions. The restructuring exercise was completed in 1978 with over 700 odd and mushroom unions giving way or being replaced with 70 registered and recognized trade, unions. The exercise got a legal backing through the promulgation of Schedule 3 of the Labour (Amendment) Decree No. 22 of 1978. The details of the types of businesses or operations and the constituent House Unions covered by the emergent Industrial Unions were shown in the Federal Republic of Nigeria Extra-Ordinary Gazettee No.6 Vol.65 of $8^{\text {th }}$ February, 1978.

\section{National Policy on Labour and Its Impact on Industrial Relations}

\subsection{Objectives of Public Policy on Industrial Relations in Nigeria}

The main objectives of public policy on industrial relations are outlined in the National Labour Policy which emerged on $4^{\text {th }}$ December, 1975. 
(i)

In pursuance of the above objectives, government expressed its interventionist policy or what it termed "Guided Democracy" in labour matter through:

The continued guarantee of freedom of association as enshrined in the constitution of Nigeria. The promotion of strong, stable and responsible workers and employers' organization;

The establishment and development of a suitable institutional framework for the effective and expeditious settlement of labour disputes;

The promotion of labour-management co-operation and consultation at appropriate level between workers, employers and government; and

The vigorous enforcement of the provisions of labour legislation relating to minimum conditions of employment social security, safety, health and welfare at work.

\subsection{Advantages of the Public on Industrial Relations in Nigeria}

There is no doubt that the emergence of industrial unions made the unions to be much bigger, much better organized and much stronger. They also have a complete coverage of the whole country: the innovation led to a rapid growth of trade union membership and has also helped in demarcating trade unions from professional associations.

The establishment of industrial unions led to the emergence of one United Central Labour Organization - Nigeria Labour Congress (NLC) to spearhead the pressure from its affiliate members on labour relations issues.

Industrial unionism led to the disappearance of different concepts of unionization within enterprises but established unions covering different cadre of employees; junior, senior and managerial staff termed three tier system of unionism.

The introduction of compulsory check-off dues not only enhanced the financial position of the unions but gave them financial muscle to employ competent hands, engage in capacity building of the skills of their rank and file membership and above all being able to meet the legitimate obligations to their members.

In view of exposure to trade union education, the union leadership push through their demands and also conduct collective bargaining in a very professional manner.

Industrial unionism paved way for the emergence of much larger number of trade unions of employers than was the situation in the past. Besides, the Trade Union Act provides for the formation of trade unions of employers.

The advent of industrial unionism created jobs for paid and full time officials who were engaged to manage the union secretariat. Some of them are crop of trained and retired Personnel Managers and Labour Officers with vast experience on labour matters. Akin to this, are subordinate and support staffs who are Social and Management Science University Graduates working, in administration, finance, research and planning units of the unions secretariats or offices.

The Industrial Arbitration Panel (IAP) and National Industrial Court (NIC) are institutions created by government to cope with the management of trade disputes and to ensure their expeditious settlement. From the foregoing, it can be seen that industrial unionism brought innovations and healthy developments to industrial relations scene in Nigeria. Besides, the role of the parties in the industrial relations system have been increasing and changing through institutionalization, legalization and professionalisation on continuous basis. 


\section{The Emergence of Industry-Wide or Multi-Employer Bagaining}

With the creation of industrial unions, industry-wide bargaining became the vogue and replaced bargaining at the plant level. Multi-employer bargaining is negotiation between the representatives of the employers (Employers Association) and representatives of workers (Trade Unions) belonging to the same occupational industry e.g. negotiation between Nigeria Employers Association of Banks, Insurance and Allied Institutions (NEABIAI) and National Union of Banks, Insurance and Financial Institutions Employees (NUBIFIE) for junior employees and Association of Senior Staff of Banks, Insurance and Financial Institutions (ASSBIFI) in the Banking industry.

Under this arrangement, the Employers Association negotiates substantive issues and discusses non-substantive ones with both the junior and senior staff unions at different sessions. Atimes, the outcomes of the negotiation are regarded as minimum standard and parties may improve on the negotiated rates at the enterprise level. Management has as final decision on the outcome of non-substantive issues.

Aside from industry-wide bargaining, the actors in industrial relations interact at two other levels to consider matters of mutual interests and problems arising from workplace situation:

\subsection{National or Tripartite Bargaining}

This is a negotiation involving the three actors in industrial relations - government, labour unions and management representatives. The essence of bargaining at this level is to lay down guidelines or perhaps, the minimum level or standard which establishments in each sector (public or private) should not go below e.g. National Minimum Wage Act.

\subsection{Joint Consultation/Single Employer Bargaining (JCC)}

Under this, parties discuss matters of mutual interest at the unit or grassroot level between the management and the workers' representatives (Shop stewards or Committee of Shop Stewards or). Matters discussed at this level are issues that are not subject of negotiation at the industrial level. It should be borne in mind that JCC issues are meant for discussion only and not mandatory or binding on the employer. Atimes, JCC can serve as an advisory body with management making the final decision.

In the event that negotiation between the parties fails through the process of collective bargaining, the Trade Disputes Act of 1976 makes allowance for voluntary settlement of disputes by parties concerned through mediatory process before resorting to external or statutory processes which involve conciliation, arbitration and adjudicatory processes.

Before the advent of industrial unionism, collective bargaining was mainly between individual enterprise or house unions and their various employers. The scene however, changed drastically with the restructuring of the erstwhile multifarious enterprise unions into industrial unions. Consequently, the emergence of industrial unionism ushered in correlative bargaining pattern which has been the subject of discourse under this subheading.

\section{Industrial Unionism and Multi-Employer Bargaining and Its Implications for Industrial Relations Practice in Nigeria}

\subsection{Merits of Multi-Employer Bargaining}

In highly competitive industries, multi-employer bargaining has been found as the only effective approach to the attainment and maintenance of high labour standards. Bargaining on a market-wide basis permits the pooling of bargaining strength and provides small employers with access to expert services in the negotiation and administration of collective agreement. Industry-wide agreements have also been found to give greater protection to the workers, establishing more uniform conditions and guaranteeing the same advantages to all including those less capable of defending themselves effectively in their own undertakings. The proper handling of industry-wide bargaining could have a stabilizing effect on the climate of industrial relations and economic development in general.

By merging several unions into one large industrial union creates room for huge savings to accrue through the elimination of duplicated posts, operations and set ups, and such savings channeled more usefully to initiate and finance better and result-oriented programmes for the mutual benefit of the unions and Employers. Following the growing tendency for co-operation in labour/management relations, industry-wide bargaining will help to prevent the unfair exploitation of a weak employer by a powerful union. Besides, taking cognizance of one of Nigeria's national objectives which focus on establishing the country firmly as a just and egalitarian society, uniform conditions of service in industry will lead not only to an equitable system of remuneration package for all employees in the industry but will also contribute immensely towards the maintenance of a stable and reasonably contented labour 
force by minimizing the unhappy tendency of experienced staff hopping from one establishment or job to another for purely economic reasons.

An industrial union represents a large family of worker with identical interests such as occupational skills, professional attainment standards; common aspiration, community of interest and service to members of the public. Therefore, it provides the members with a greater opportunity (i) to share their experiences with co-workers from different parts of the same industry, and (ii) to appreciate the high cost of mutual antagonism; the same measure also applies to industry-wide employer union.

\subsection{Demerits of Multi-Employer Bargaining}

However, critics of industrial unionism are of the opinion that the system tends to be too unwieldy and could lead to possible neglect of the interests of some sections or units of the workforce with its attendant repercussions. It was further argued that the welfare of the more productive employee could be jeopardized in an attempt to equalize their terms and conditions of service with those of the less productive employees in the industry.

The system carries along with it the problem of ability/inability to pay. For instance, there are often considerable differences between one firm and another.

The best managed and most prosperous firms in an industry may be able to pay agreed rates higher than those which the least prosperous firms can afford. Consequently, if rates of wages and conditions of employment are fixed too high for the poorer firms, they may be forced to rationalise their staff. Akin to this, if unemployment becomes substantial, the union will find their bargaining position weakened as they may also lose members. The trend will in turn affect their financial position adversely.

There is also the problem of size discomfiture. The sheer size involved in multi-employer bargaining is not without some disadvantages. Wage gains through industry-wide bargaining may lead to inflationary trends. On the other hand, multi-employer bargaining could lead to public discomfort in the event of industrial work stoppage.

In the era of house union dispensation, negotiation takes place in most cases under a friendly, cordial and familiar atmosphere because parties work in the same company and share a common work environment. However, under industry-wide negotiations, workers' and employers' representatives are invariably strangers to themselves because they work in different firms but have to come together at the bargaining table. They need considerable time before they can be used to each other and play the game co-operatively in a win-win like manner.

\section{Recommendations for Effective Multi-Employer Bargaining}

The underlisted tips may be useful to parties in achieving a stable, prosperous and peaceful atmosphere in the course multi-employer bargaining in the workplace:

(i)

(iii)
In bargaining under the multi-employer system, the parties must always keep in mind, the effects of any given level of wages and conditions of employment on the smaller firms. The rates fixed in the collective agreement must be closely related to ability to pay.

In the process of bargaining, both sides must recognize that the employers ability to make concessions and the trade unions ability to obtain improved working conditions

for their members will to a large degree depend on the state of the national economy and general level of business activity. Periods of slump, recession and depression must receive equal recognition with periods of boom and profitability. Furthermore, the parties in labour relations must work closely with government. In this respect, there is needed to take proper account of the economy and above all be guided by national interests in the course of collective bargaining process.

Both parties must be prepared to work towards common grounds instead of concentrating on dispute-stimulating issues. It pays both parties to recognize and acknowledge each other's indispensability as work-partners; extend mutual concerns beyond the familiar issues of wages, hours of work and other conditions; discuss and dispose of problems as they arise without recourse to a third party intervention. In a nutshell parties should accept that a constant reduction of the incident of conflict is a concomitant of industrial progress.

There is the dire need for parties to comply or adhere strictly with the procedural agreements. The provision of the sanctity of the document must be respected if conflict is to be avoided in labour relations. The central and local negotiable items must be recognized, separated and treated so. 
(v)

The effective gathering of information through research activities has become imperative in the present day bargaining process. Both sides must arm themselves with necessary background information and knowledge before the actual negotiation. For instance, parties must be conversant with the wage rates and conditions of employment in each of the component firms, wage differentials and relativities within and outside the industry, the level of prices and cost of living, governing legislation on the items listed for negotiation etc. These information are necessary for usage during bargaining sessions. Besides, the possession and presentation of some of these information will not only be time-saving but will also prevent confrontation and protracted negotiations.

Due to the size and heterogeneous nature of industrial unions, the parties must be prepared to be flexible and avoid making extreme demands which are unrelated to the nature and size of their industry and also the ability to pay must be factored.

During bargaining sessions, both parties must exhibit the spirit of "give and take". In some occasions, the parties may not reach agreement in a short-while but there must be at least a genuine effort to do so. It is truism that no bargaining context exists where workers make a demand and refuse to consider counter proposals or where employers make counter proposals and the workers after listening to the facts and arguments invoked in support reject them flatly. In equal vein, employers should not dismiss with a wave of the hand, original or counter-demands put forward by the union. Each side may take a firm and strong line, but allowance must be made for possible compromise between the originally incompatible demands or claims of the two sides.

There is need to give members of the bargaining team appropriate and relevant training in the art of collective bargaining especially the union side. The process of collective bargaining will be worthless when undertaken by representatives who have no sufficient knowledge of the art, concept or language being used and the implications of their representation. The representatives should therefore be given adequate training and carefully selected to ensure full and fruitful participation in the bargaining exercise.

Considering the fact that efficiency and productivity are very vital to the growth of the national economy, parties involved in multi-employer bargaining should strive to arrive at consensus on ways of improving efficiency and productivity. It is through this means that the aspirations of our people for a better quality of work life (QWL) can attained and sustained.

The parties should consider very carefully on each side the need for unity and concerted effort as the only effective weapon and strategy for a stronger and virile industrial unions for the mutual benefits of all affiliating member unions and employers alike. It is obvious that apparent differences exist among the various units that makes up the union on both sides, but the principle and rule of the game should be accepted: "in unity and concerted effort we stand", therefore there are no problems that cannot be resolved amicably to the mutual advantage of the parties and the nation at large.

\section{Conclusion}

Without prejudice to the maintenance of the reputation of the actors in our industrial relations system as good employers and responsible representatives of workers (trade unions), the pooling of expertise in the conduct of collective bargaining and allied matters will no doubt augurs well for all the parties involved in industrial unionism rather than dissipating energy and efforts on individual basis. Besides, the desirability of ensuring that relatively small firms survive in the midst of large and stronger ones cannot be over-emphasized under the dispensation of industrial unionism. However, the common and laudable objective is to keep all members of the fold on both sides within the fold and not to alienate any of them. That is likely to be the way and perhaps the way out.

\section{References}

Aborishade, F. (1992). Nigerian Labour Movement in Perspective, Lagos: The Effective Company.

Ademiluyi, T.A., \& Imhonopi, D.F. (2010). Trade Union Dynamism in a Bellgerent State-Nigeria Between 1980-2007. Journal of Economics and Engineering.

Adewumi, F. (1997). Trade Unionism in Nigeria: Challenges of the $21^{\text {st }}$ Century. Lagos, Friedrich Ebert Foundation. 
Adewumi, F. (2004). Ideological Posturing and Trade Union Leadership in Nigeria (The Story of Comrade Ali Chiroma). Hure Prints, Ibadan.

Anyim, F. C. (2009). A Critique of Trade Disputes Settlement Mechanism in Nigeria: 1968 to 2004. Unpublished Ph.D Thesis, University of Lagos, Nigeria.

Fashoyin, Tayo. (1980). Industrial Relations in Nigeria. Longman, Nigeria Press.

Fashoyin, Tayo. (1992). Industrial Relations in Nigeria ( $2^{\text {nd }}$ ed.). Longman, Nigeria Press.

Federal Republic of Nigeria Extra-ordinary Gazettee, No.6, Vol.65 of $8^{\text {th }}$ Feb. 1978.

Imhonopi, D., \& Urim, U.M. (2011). The Development of Labour Movements and State Interference: The Nigerian Experience. Journal of Sustainable Development in Africa, 13(2).

Mulvey, C. (1978). The Economic Analysis of Trade-Unions. Oxford Martin Robertson and Co. Ltd.

Offiong, D. A. (1983). Organised Labour and Political Development in Nigeria. Calabar Centaur Press.

Okogwu, G.C. (1996). Decentralization of Trade Unions: Implications for Industrial Relations Practice in the Banking Industry. Paper Presented at NBEG's $2^{\text {nd }}$ National Seminar on Industrial Relations held in Lagos.

Omolayole, M.O. (1977, October). The Likely Impact of Industrial Unionism on Industrial Relations Practice in Nigeria. Journal of the Institute of Personnel Management in Nigeria, 4.

Otobo, D. (1986). Foreign Interests and Nigerian Trade Unions. Ibadan: Heinemann Educational Books (Nig) Ltd.

Otobo, D. (1996). The Theory and Practice of Industrial Relations and Trade Unionism in Nigeria: A General Theoretical Framework. Paper Presented at NBEG's $2^{\text {nd }}$ National Seminar on Industrial Relations held in Lagos.

Report of the National Conference on Industrial Relations, Lagos, $15^{\text {th }}-20^{\text {th }}$ Nov., 1965.

Second and Final Report of the Wages and Salaries Review Commission, 1970-1971.

Tar, U. A. (2009). Organised Labour and Democratic Struggles in Nigeria. Information, Society and Justice, 2(2). 